International Journal of Business Management and Economic Review

Vol. 4, No. 04; 2021

ISSN: 2581-4664

\title{
THE EFFECT OF PROMOTION ON IMPULSE BUYING WITH SHOPPING EMOTION AS A MEDIATION VARIABLE
}

\author{
Komang Yuni Anita and Ni Made Wulandari Kusumadewi \\ Faculty of Economics and Business, Udayana University, Bali, Indonesia
}

http://doi.org/10.35409/IJBMER.2021.3300

\begin{abstract}
This study aims to determine the role of shopping emotion in mediating the effect of promotion on impulse buying. The population in this study were consumers of Wardah cosmetic products in Denpasar City. The method of determining the sample is done by non-probability sampling method, through purposive sampling technique so that the number of samples used is 96 respondents. Data collection is done through a questionnaire. The analysis technique used is path analysis technique. The results showed that promotion had a positive and significant effect on shopping emotion, promotion had a positive and significant effect on impulse buying, shopping emotion had a positive and significant effect on impulse buying, and shopping emotion was able to mediate the effect of promotion on impulse buying. The results of the study also reveal that the importance of the promotion role carried out by producers is to be able to increase consumer interest and desire to make purchases, especially impulse purchases. In addition to promotion, producers must be able to stimulate and influence consumer emotions to choose to use Wardah cosmetics by making consumers feel interested, satisfied, happy and comfortable when shopping for Wardah cosmetic products.
\end{abstract}

Keyword: Promotion, Shopping Emotion, Impulse Buying.

\section{INTRODUCTION}

Nowadays promotion is one of the ways that companies need to increase sales volume. Promotion is one of the activities to stimulate consumers to make purchases, especially impulse buying behavior. A trained salesperson can reduce frustration by guiding and assisting consumers in the buying process and activating impulse buying behavior (Iqbal, et al., 2014). The promotion that most affects consumers is advertising, where the positive influence of advertising can increase the thinking of buying goods by consumers (Vishnu and Raheem, 2013). Appropriate promotions such as using advertising services and coupled with using attractive brand ambassadors to convey the promotions provided by manufacturers such as giving discounts can encourage consumers' emotional interest in impulse buying behavior.

Promotional activities also aim to provide interesting information related to the products being sold as well as convenience that can be obtained by consumers when shopping. The convenience that consumers get when shopping, whether shopping directly at a beauty product store or retail, is the availability of non-cash payments using a debit or credit card from a bank and being able to obtain the right information and promotions offered for the desired beauty product from sales 


\section{International Journal of Business Management and Economic Review}

Vol. 4, No. 04; 2021

ISSN: 2581-4664

or salespeople. Convenience can also be obtained by consumers by shopping for Wardah products online, namely being able to transact via mobile banking and information about products and promotions are usually clearly available on the available pages. The phenomenon of the ease of transactions can be a strong impetus for consumers to behave in impulse buying.

Several studies related to the effect of promotion on impulse buying, among others, were carried out by Kharis (2010), Kurniawan \& Kunto (2013), Putra (2014), Indraswari \& Martono (2016) and Aini, et al (2016) stated that promotion had a positive effect on impulse buying. . The results of research conducted by Banerjee \& Sunetra (2012) found that promotional activities through discounts and discounts trigger impulse buying. Tendai \& Chipunza (2009) stated that coupons and shopping vouchers affect impulse buying. Incompatible results were obtained by Kurniawati \& Restuti (2003); Sari \& Hermawati (2020) which stated that promotion had no effect on impulse buying.

The inconsistency of the results of previous research indicates that there are other factors that can influence the relationship between promotion and impulse buying, namely shopping emotion or consumer emotion (Aini, et al., 2016). Emotion as an internal factor can be an intermediary that encourages consumers' feelings to be more interested in the promotions provided by producers so that they eventually behave in impulse buying. Hawkins, et al. (2007:383) states that emotions can be identified as feelings of liking or disliking something more specific. Emotions are also one of the factors that influence impulse buying. Emotions are generally triggered by environmental events. Solomon (2017) explains that a person's mood or emotions or a person's psychological state at the time of purchase can have a major impact on what he buys or how he evaluates his purchase. Two emotional dimensions that can influence consumer behavior in shopping, namely pleasure (pleasure) and arousal (arousal) (Rossiter \& Bellman, 2005). These two emotional dimensions have a major influence on consumers' willingness to spend more time in the store and also buy more.

Several previous studies related to the relationship between shopping emotion and impulse buying were carried out by Wauran \& Poulan (2016) and Aini, et al (2016) which stated that shopping emotion had a positive effect on impulse buying. Different results were obtained by Jauhari (2017) which stated that shopping emotion had a negative effect on impulse buying. Based on the explanation above, there is a growth phenomenon in the cosmetics industry, one of which is Wardah cosmetics manufacturer which triggers consumers to make impulse buying and the finding of inconsistencies from previous studies makes researchers interested in conducting research again on the effect of promotion on impulse buying with shopping emotion as a mediating variable.

\section{LITERATURE REVIEW AND HYPOTHESES DEVELOPMENT}

Rangkuti (2009) states that promotion is a company's effort to influence and stimulate consumers to buy products through product introduction and providing incentives. Providing incentives by producers in the form of price discounts will provide emotional stimulation to consumers. Emotions can be conceptualized as a dimension of positive feelings such as a sense of comfort, pleasure, enthusiasm that is formed due to the interaction of the sensory components of the human senses to the atmosphere around them, so that consumers will feel happy and enthusiastic about the products offered. Today's consumer behavior has changed to become more frugal, where consumers want a greater emphasis on value and an increased focus on convenience 


\section{International Journal of Business Management and Economic Review}

Vol. 4, No. 04; 2021

ISSN: 2581-4664

(Rittipant et al., 2013).

Research from Kurniawan \& Kunto (2013), Kumiawati \& Restuti (2014) and Winawati (2015) states that promotion has a positive and significant effect on shopping emotion. This means that the better the promotions carried out by producers, the better the shopping emotions of consumers.

H1: promotion has a positive and significant effect on shopping emotion

Kotler (2007) which states that sales promotion as the main element in marketing campaigns are various collections of incentive tools designed to stimulate faster or greater purchase of certain products or services by consumers. Promotional activities can cause an excitement to buy which is a behavioral stimulus to satisfy the needs of life (Fiske, 2007: 245). Promotion plays a very important role in increasing short-term sales volume which directly attracts consumers to make impulse buying. Engel et al., (2008:386), stated that impulse buying (unplanned purchase) is a purchase that occurs when consumers experience a sudden feeling, full of power and a strong urge to buy a product immediately, this is very likely to happen if manufacturers carry out interesting promotional activities.

The results of research conducted by Liao, et al., (2009), Kumiawan \& Kunto (2013), and Putra (2014) state that promotion has a positive and significant effect on impulse buying. The results of this study are in line with research conducted by Sari \& Suryani (2014) which states that the better the promotional activities carried out, the higher the impulse buying.

$\mathrm{H} 2$ : promotion has a positive and significant effect on impulse buying.

A person's mood or emotions can be influenced by store design, weather, or factors that consumers feel are sensitive to. So, emotion is one important aspect that needs to be considered in influencing consumers and potential consumers because it can encourage consumers to make purchases without being held back (Nandha, et al., 2013). Park \& Lennon (2006) found that impulse buying behavior is almost exclusively controlled by stimuli. Impulsive buyers are likely to be open and flexible to thoughts of sudden purchases or unexpected purchases because of strong emotions or urges to buy a product.

Research conducted by Kurniawan \& Kunto (2013), Kurniawati \& Restuti (2014), Theresia (2014), Supriono (2017) and Aurellia (2019) stated that shopping emotion has a positive and significant effect on Impulse Buying. This shows that the higher the shopping emotion of consumers, the higher the level of impulse buying (unexpected purchases).

H3: shopping emotion has a positive and significant effect on impulse buying

Consumer behavior is the decision-making process and physical activities of individuals involved in evaluating, obtaining and using goods and services (Kotler, 2003). Engel et al., (2008: 386), define impulse buying as a purchase that occurs when consumers experience a sudden feeling, full of strength and a strong urge to buy something immediately. Impulse buying can occur because consumers feel they get a stimulus from promotions made by producers. These promotional activities can provide additional incentives that make consumers feel more emotional than rational thinking.

The results of research conducted by Kurniawan \& Kunto (2013) and Rani \& Purnami (2019) stated that shopping emotion was able to mediate the effect of promotion on impulse buying.

$\mathrm{H} 4$ : shopping emotion is able to mediate the effect of promotion on impulse buying.

\section{RESEARCH METHODS}


This research was conducted in Denpasar City. The reason for choosing Denpasar City as the research location is because it is an urban area with a very fast growth of the economic sector of the community, so it can be said that the people in Denpasar City have purchasing power which tends to be higher than other cities in Bali. In addition, technically Denpasar City is a location that has met the categories that are considered effective and efficient in conducting relevant research. The time of this research was carried out in 2020.

The population used in this study were all consumers in Denpasar City who had used Wardah cosmetic products. The method of determining the sample is done by non-probability sampling technique with purposive sampling method with the following criteria:

1) Have a minimum education of high school / equivalent, because they are considered to be able to answer the questionnaire questions well.

2) Respondents have done impulse buying.

3) Respondents have made purchases of Wardah cosmetic products at least 2 times during the last 6 months.

For the ideal number of samples is 5-10 the number of variables or indicators. The number of indicators in this study were 12 indicators, so the number of samples in this study was 90 respondents.

The research hypothesis testing was carried out using a path analysis model and data processing using the Product and Service Solutions (SPSS) version 18 application program. The path analysis model was used to analyze the pattern of relationships between variables with the aim of knowing the direct or indirect effect of a set of independent variables on the dependent variable.

\section{RESULTS AND DISCUSSION}

Respondent characteristics data is respondent data collected to determine the profile of research respondents. Characteristics of respondents in this study include: respondent's age, gender, and education level. These measurements were obtained from the results of returning the research questionnaire. The characteristics of the respondents are presented in Table 1.

\section{Table 1. Characteristics of Respondents}

\begin{tabular}{|llll|}
\hline No & Description & Total & Percentage (\%) \\
\hline 1 & Age & 18 & \\
& $<25$ years old & 32 & 18,75 \\
& $>25-35$ years old & 25 & 33,33 \\
& $>35-45$ years old & 21 & 26,04 \\
& $>45$ years old & $\mathbf{9 6}$ & 21,88 \\
\hline & Total & $\mathbf{1 0 0 , 0 0}$ \\
\hline & Gender & 21 & 21,88 \\
\hline & Male & 75 & 78,12 \\
\hline & Female & $\mathbf{9 6}$ & $\mathbf{1 0 0 , 0 0}$ \\
\hline 3 & Total & & \\
\hline & Education Background & 6 & 6,25 \\
\hline & Senior High School & & \\
\hline
\end{tabular}


International Journal of Business Management and Economic Review

Vol. 4, No. 04; 2021

ISSN: 2581-4664

\begin{tabular}{|lll|}
\hline \hline Diploma & 25 & 26,04 \\
Bachelor & 50 & 52,08 \\
Post Graduated & 15 & 15,63 \\
\hline
\end{tabular}

Primary Data, 2021

Based on Table 1, it is known that the respondents in this study were 18 consumers of Wardah cosmetics aged less than 25 years with a percentage of 18.75 percent, Wardah cosmetics consumers aged more than 25-35 years were 32 people with a percentage of 33, 33 percent. Meanwhile, Wardah cosmetics consumers aged more than 35-45 years amounted to 25 people with a percentage of 26.04 percent and the remaining 21.88 percent were Wardah cosmetics consumers aged more than 45 years. Based on this, it is known that most of the research respondents are aged between 25-35 years. Wardah cosmetic consumers in Denpasar City who became research respondents were mostly female with a percentage of 78.12 percent and the remaining 21.88 percent were male. This shows that women who dominate as consumers of Wardah cosmetic products are women. Most of Wardah's cosmetic consumers who became research respondents had a bachelor's level of education with a percentage of 52.08 percent. For high school education, the percentage is 6.25 percent, diploma is 26.04 percent, while the remaining 15.63 percent are Wardah cosmetics consumers with postgraduate education.

Path Analysis Results

Testing the research hypothesis was carried out using a path analysis model and data processing using the Product and Service Solutions (SPSS) version 22 application program. This study used one dependent variable, namely impulse buying, one independent variable, namely promotion, and one mediating variable, namely shopping emotions.

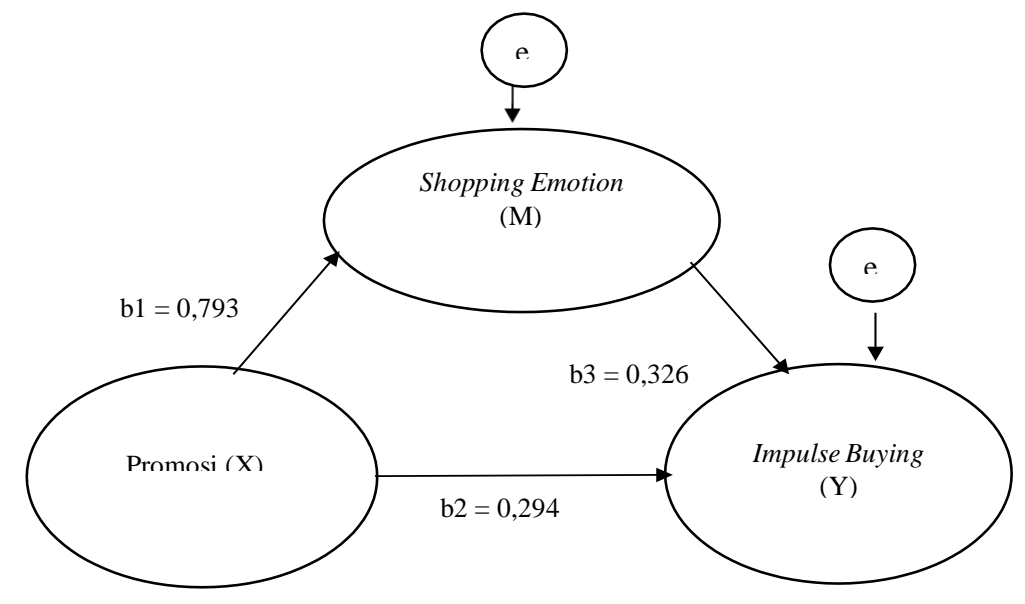

Figure 1. Research Model

The research data was processed using path analysis, with the help of the SPSS version 18 for windows program, so that the results of data processing can be seen in Table 2 and Table 3.

Table 2. Results of Path Analysis of the Effect of Promotion on Impulse Buying

\begin{tabular}{|lllll}
\hline $\begin{array}{l}\text { Unstandardized Coefficient } \\
\text { Model }\end{array}$ & Btd. Error & $\begin{array}{l}\text { Standardized } \\
\text { Coefficient }\end{array}$ & t & Sig.
\end{tabular}


International Journal of Business Management and Economic Review

Vol. 4, No. 04; 2021

ISSN: 2581-4664

\begin{tabular}{|llllll|}
\hline \hline & & Beta & \\
\hline Constanta & 10,005 & 1,365 & & 7,329 & 0,000 \\
Promotion & 1,270 & 0,101 & 0,793 & 12,635 & 0,000 \\
$\mathrm{R}^{2}$ & & 0,629 & & & \\
Adjusted $\left(\mathrm{R}^{2}\right)$ & & 0,625 & & & \\
$\mathrm{~F}$ & & 159,650 & & & \\
Sig. F & & 0,000 & & & \\
\hline
\end{tabular}

Primary Data, 2021

Based on Table 2, the structural equations can be arranged as follows:

$\mathrm{M}=10.005+1.270 \mathrm{X}$

The Effect of Promotion on Shopping Emotion

The first hypothesis (H1) proposed in this study is that promotion has a positive and significant effect on shopping emotion. The results presented in Table 2 show that the beta coefficient $(\beta 1)$ is 1.270 with a significance level of 0.000 less than 0.05 . This means that promotion has a positive and significant effect on the shopping emotion of Wardah cosmetics consumers. The better the promotion is done it will increase the shopping emotion of Wardah cosmetics consumers.

These results are supported by the results of research conducted by Rangkuti (2009) which states that promotion is a company's effort to influence and stimulate consumers to buy products through product introductions and incentives. Providing incentives by producers in the form of price discounts will provide emotional stimulation to consumers. Cosmetics manufacturer Wardah has also implemented promotions in the form of discounting prices, giving attractive bonuses and giving lucky draws that can stimulate consumer emotions. The results of this study are also supported by the results of research conducted by Kurniawan \& Kunto (2013), Kumiawati \& Restuti (2014) and Winawati (2015) which also stated that promotion had a positive and significant effect on shopping emotion.

Table 3. Results of Path Analysis Equation of the Effect of Promotion and Shopping Emotion on Impulse Buying

\begin{tabular}{|llllll|}
\hline $\begin{array}{l}\text { Unstandardized Coefficient } \\
\text { Model }\end{array}$ & Std. Error & $\begin{array}{l}\text { Standardized } \\
\text { Coefficient } \\
\text { Beta }\end{array}$ & t & Sig. \\
\hline Constanta & 4,257 & 1,400 & & & \\
Promotion & 0,288 & 0,135 & 0,294 & 2,040 & 0,003 \\
Shopping Emotion & 0,199 & 0,084 & 0,326 & 2,368 & 0,035 \\
$\mathrm{R}^{2}$ & 0,3444 & & & & \\
Adjusted $\left(\mathrm{R}^{2}\right)$ & 0,330 & & & & \\
F & 24,393 & & & & \\
Sig. F & 0,000 & & & & \\
\hline
\end{tabular}

Primary Data, 2021

Based on Table 3, the structural equations can be arranged as follows:

$\mathrm{Y}=4.257+0.288 \mathrm{X}+0.199 \mathrm{M}$ 


\section{International Journal of Business Management and Economic Review}

Vol. 4, No. 04; 2021

ISSN: 2581-4664

The Effect of Promotion on Impulse Buying

The second hypothesis $(\mathrm{H} 2)$ put forward in this study is that promotion has a positive and significant effect on impulse buying. The results presented in Table 3 show that the beta coefficient $(\beta 2)$ is 0.288 with a significance level of 0.035 less than 0.05 . This means that promotion has a positive and significant effect on impulse buying of Wardah cosmetic consumers. The better the promotion is done it will increase impulse buying from Wardah cosmetic consumers.

Promotion plays a very important role in increasing short-term sales volume which directly attracts consumers to make impulse buying. Engel et al., (2008:386), stated that impulse buying (unplanned purchase) is a purchase that occurs when consumers experience a sudden feeling, full of power and a strong urge to buy a product immediately, this is very likely to happen if manufacturers carry out interesting promotional activities. The existence of promotions in the form of discounted prices and attractive bonuses provided by Wardah cosmetic manufacturers will make consumers interested in buying Wardah cosmetic products even though the purchase was not planned in advance.

The results of this study are also supported by research conducted by Liao, et al., (2009), Kumiawan \& Kunto (2013), and Putra (2014) which state that promotion has a positive and significant effect on impulse buying. The results of this study are in line with research conducted by Sari \& Suryani (2014) which states that the better the promotional activities carried out, the higher the impulse buying.

The Effect of Shopping Emotion on Impulse Buying

The third hypothesis (H3) put forward in this study is that shopping emotion has a positive and significant effect on impulse buying. The results presented in Table 3 show that the beta coefficient $(\beta 3)$ is 0.199 with a significance level of 0.020 less than 0.05 . This means that shopping emotion has a positive and significant effect on impulse buying for Wardah cosmetics consumers. This shows that the better the shopping emotion of consumers, the higher the level of impulse buying from Wardah cosmetics consumers.

According to (Nandha, et al., 2013), a person's mood or emotions can be influenced by store design, weather, or factors that consumers feel are sensitive. So, emotion is one important aspect that needs to be considered in influencing consumers and potential customers because it can encourage consumers to make purchases without being held back. Park \& Lennon (2006) found that impulse buying behavior is almost exclusively controlled by stimuli. Impulsive buyers are likely to be open and flexible to thoughts of sudden purchases or unexpected purchases because of strong emotions or urges to buy a product. When Wardah cosmetic consumers feel satisfied, comfortable and interested in Wardah cosmetic products, emotionally it can effect consumer purchasing decisions to make impulse buying.

The results of this study are also supported by research conducted by Kurniawan \& Kunto (2013), Kurniawati \& Restuti (2014), Theresia (2014), Supriono (2017) and Aurellia (2019) stating that shopping emotion has a positive and significant effect on Impulse Buying. 


\section{International Journal of Business Management and Economic Review}

Vol. 4, No. 04; 2021

ISSN: 2581-4664

Shopping Emotion Mediate The Effect of Promotion on Impulse Buying

The fourth hypothesis (H4) put forward in this study is that shopping emotion mediates the effect of promotion on impulse buying. The results showed that the Sobel test results were 2.179 more than 1.96. This means that shopping emotion mediates the effect of promotion on impulse buying of Wardah cosmetic consumers. This shows that the better the promotion given by the producers and the shopping emotion from the consumers, the higher the impulse buying rate from Wardah cosmetics consumers.

Consumer behavior is the decision-making process and physical activities of individuals involved in evaluating, obtaining and using goods and services (Kotler, 2003). Engel et al., (2008: 386), define impulse buying as a purchase that occurs when consumers experience a sudden feeling, full of strength and a strong urge to buy something immediately. Impulse buying can occur because consumers feel they get a stimulus from promotions made by producers. These promotional activities can provide additional incentives that make consumers feel more emotional than rational thinking. When Wardah cosmetics consumers are given promotions in the form of price discounts, raffle prizes and attractive bonuses will stimulate their emotions to be interested in impulse buying from Wardah cosmetic products.

The results of this study are also supported by the results of research conducted by Kurniawan \& Kunto (2013) and Rani \& Purnami (2019) stating that shopping emotion is able to mediate the effect of promotion on impulse buying.

\section{Managerial Implications}

This study is able to explain the models and theories that underlie the influence of promotion on impulse buying mediated by shopping emotion. The results of the study reveal that the importance of the promotion role carried out by producers is to be able to increase consumer interest and desire to make purchases, especially impulse purchases. In addition to promotion, producers must be able to stimulate and influence consumer emotions to choose to use Wardah cosmetics by making consumers feel interested, satisfied, happy and comfortable when shopping for Wardah cosmetic products. The limitations of this study, among others, are related to factors that influence impulse buying in this study, namely promotion and consumer shopping emotion, while there are many other factors that affect impulse buying such as gender, consumer confidence, and ease of shopping.

\section{CONCLUSION}

Promotion has a positive and significant effect on shopping emotion on consumers of Wardah cosmetic products in Denpasar City. These results indicate that the more attractive the promotions offered by Wardah's cosmetic products through the provision of discounts, attractive bonuses and raffle prizes to consumers, the better consumer shopping emotions are formed.

Promotion has a positive and significant effect on impulse buying for consumers of Wardah cosmetic products in Denpasar City. These results indicate that the more attractive the promotions offered by Wardah cosmetic products to consumers through the provision of discounts, attractive bonuses and raffle prizes to consumers, the higher the unplanned buying behavior of consumers.

Shopping emotion has a positive and significant effect on impulse buying on consumers of Wardah cosmetic products in Denpasar City. These results indicate that the better the consumer's feelings when interacting when shopping for Wardah cosmetic products are happy, comfortable, 


\section{International Journal of Business Management and Economic Review}

Vol. 4, No. 04; 2021

ISSN: 2581-4664

satisfied, like, interested, and excited, the tendency of consumers to make impulse purchases is also increasing.

Shopping emotion mediates the effect of promotion on impulse buying of consumers of Wardah cosmetic products in Denpasar City. These results indicate that an attractive promotion of Wardah cosmetic products, supported by consumer shopping emotions in the form of feelings of pleasure and interest in making a purchase, can further increase consumers' unplanned buying behavior.

\section{REFERENCES}

Aini, Q. A., Suharyono \& Hidayat K. (2016). Pengaruh Atmosfer Toko Dan Promosi Penjualan Terhadap Shopping Emotion Dan Pembelian Tidak Terencana (Survei Terhadap Konsumen Giant Hypermarket Mall Olympic Garden). Jurnal Administrasi Bisnis. Vol 37 No. 1.

Aurellia, Dinda Prasetya. (2019). Pengaruh Persepsi Konsumen Pada Store Atmosphere Terhadap Impulse Buying Melalui Shopping Emotion Pleasure. EXERO Journal of Researchin Businessand Economics. Vol. 2 No. 01.

Banerjee, S., \& Sunetra, S. (2012). Impulse Buying Behaviour Retail Stores- Triggering The Sense. Asia Pacific Journal of Marketing \& Management Review, 1(2), pp: 1-21.

Engel, J.,Roger D. \& Paul W. (2008). Perilaku Konsumen.Alih Bahasa: Budyanto. Jilid I.. Jakarta: Binarupa Aksara Publisher.

Hawkins, D.I., Mothersbaugh, D.L., \& Best, R.J., (2004). Consumer Behavior: Building Marketing Strategy (10th Ed.). New York: The McGraw-Hill Companies, Inc.

Indraswari, G. R. \& Martono, S. (2016). Pengaruh Promosi Terhadap Impuls Buying Dengan Gender Sebagai Variabel Dummy. Journal of Management Analysis. Vol 5 No. 2.

Iqbal, A., Akhtar, S. \& Lodhi, R. N. (2014). Determinants of Impulsive Buying for Clothing In Pakistan. British Journal of MarketingStudies. 2(8).

Jauhari, M. (2017). Pengaruh Promosi, Diskon, Merek, Store Atmosphere, Dan Shopping Emotion Terhadap Impulse Buying Di Kalangan Mahasiswa Fakultas Ekonomi Universitas PGRI Yogyakarta. Jurnal Ekonomi.

Kharis, F. (2010). Studi Mengenai Impulse Buying Dalam PenjualanOnline. Jurnal Nasional.

Kontan. (2019). Sejarah dan Pertumbuhan Penjualan Produk Wardah. www.industri.kontan.co.id, diakses: 1 September 2020.

Kotler, P. (2003). Marketing Management. 8th ed. Upper Saddle River, NewJersey: PrenticeHall.

Kurniawan, D. \& Kunto, Y. S. (2013). Pengaruh Promosi dan Store Atmosphere Terhadap Impuls buying dengan Shoping Emotion Sebagai Variabel Intervening Studi Kasus di Matahari Departement Store Cabang Supermall Surabaya. Jurnal Manajemen Pemasaran $1(2): 1-8$.

Kurniawati, D., \& Restuti, S. (2014). Pengaruh Sales Promotion Dan Store Atmosphere Terhadap Shopping Emotion Dan Impulse Buying Pada Giant Pekanbaru. Jurnal Tepak Manajemen Bisnis. 6(3) pp: 24-37.

Liao, S., Shen, Y., \& Chu, C. (2009). The Effectof Sales Promotion Strategy, Product Appeal and Consumer Traits on Reminder Impulse Buying Behaviour. International Journal of Consumer Studies. Vol. 33 Issue 3. 
International Journal of Business Management and Economic Review

Vol. 4, No. 04; 2021

ISSN: 2581-4664

Nandha O., Srikandi K., \& Hidayat. (2013). Pengaruh Faktor Situasional Terhadap Emotional States dan Impulse Buying (Survei pada Pengunjung Giant Hypermarket Mall Olympic Garden Malang). Jurnal Aplikasi Manajemen, 9(4), Hal : 88-96.

Park, J. \& Lennon, J. (2006), Psychological and Environmental Antencendents of Impulse Buying Tendency In The Multichannel Shopping Context, Journal of Consumer Marketing, vol. 23, no. 2, p. 58- 68

Putra, B. P. (2014). Analisis Pengaruh Promosi, Emosi Positif Dan Store Environment Terhadap Perilaku Impulse Buying. Diponegoro Journal Of Management. 3(4), Hal: 1-11

Rani, N. P K. D \& Purnami N. M. (2019). Peran Shopping Emotion Dalam Memediasi Pengaruh Atmosfer Ritel Dan Promosi Terhadap Impulse Buying.E-Jurnal Manajemen. Universitas Udayana Vol. 8 No. 6.

Rittipant, et al. (2013). Thai Consumer Response To Sales Promotions For Personal Care Products. International Conference on Engineering, Project, and Production Management .pp: 700-709

Rossiter, J. R. \& Bellman, S. (2005). Marketing Communication Theory and Applications. Malaysia: Perason Prentice Hall.

Sari, T.A.D. \& Suryani, A. (2014). Pengaruh Merchandising, Promosi, dan Toko Terhadap Impulse Buying. Jurnal Manajemen. 3(4): 851-867.

Sari, N. Y. \& Hermawati, S. (2020). The Effect Of Shopping Lifestyle, Hedonic ShoppingMotivation, And Sales Promotion On Impulse Buying Behavior In ECommerce (Case Study Of Berrybenka Consumer). Jurnal Ilmiah Ekonomi danBisnis. Vol. 25 No. 1.

Solomon, M. R. (2007). Consumer Behavior: Buying, Having, and Being. New Jersey, Upper Saddle River: Pearson Educatio n, Inc.

Tendai, M. \& Chipunza C. (2009). In-store Shopping Environment and Impulsive Buying. African Journal of Marketing Management. Vol. 1 (4): pp.102-108.

Theresia, V. M. (2014). Faktor-Faktor Yang Memengaruhi Pembelian Impulsif Pada Remaja Gereja GMIM Wilayah Manado Winangun. Jurnal Riset Bisnis dan Manajemen. 2(4), hal:60-72.

Vishnu, P. \& Raheem, A. R. (2013). Factors Influencing ImpulseBuying Behavior. European Journal Of Scientific Research. 100(3).

Wauran, P. \& Poluan, J. G. (2016). Pengaruh Promosi Penjualan Dan Servicescape Terhadap Impulse Buying Dengan Shopping Emotion Sebagai Variabel Intervening. Jurnal Berkala Ilmiah Efisiensi. Vol. 16 No. 4. 